IZA DP No. 9539

Self-Employment amongst Migrant Groups in England and Wales: New Evidence from Census Microdata

Ken Clark

Stephen Drinkwater

Catherine Robinson

November 2015 


\title{
Self-Employment amongst Migrant Groups in England and Wales: New Evidence from Census Microdata
}

\author{
Ken Clark \\ University of Manchester and IZA \\ Stephen Drinkwater \\ University of Roehampton, CReAM, UCL and IZA \\ Catherine Robinson \\ University of Kent
}

\section{Discussion Paper No. 9539 \\ November 2015}

\author{
IZA \\ P.O. Box 7240 \\ 53072 Bonn \\ Germany \\ Phone: +49-228-3894-0 \\ Fax: +49-228-3894-180 \\ E-mail: iza@iza.org
}

\begin{abstract}
Any opinions expressed here are those of the author(s) and not those of IZA. Research published in this series may include views on policy, but the institute itself takes no institutional policy positions. The IZA research network is committed to the IZA Guiding Principles of Research Integrity.

The Institute for the Study of Labor (IZA) in Bonn is a local and virtual international research center and a place of communication between science, politics and business. IZA is an independent nonprofit organization supported by Deutsche Post Foundation. The center is associated with the University of Bonn and offers a stimulating research environment through its international network, workshops and conferences, data service, project support, research visits and doctoral program. IZA engages in (i) original and internationally competitive research in all fields of labor economics, (ii) development of policy concepts, and (iii) dissemination of research results and concepts to the interested public.
\end{abstract}

IZA Discussion Papers often represent preliminary work and are circulated to encourage discussion. Citation of such a paper should account for its provisional character. A revised version may be available directly from the author. 


\section{ABSTRACT \\ Self-Employment amongst Migrant Groups in England and Wales: New Evidence from Census Microdata*}

Self-employment constitutes a vital part of the economy since entrepreneurs can provide not only employment for themselves but also for others. The link between self-employment and immigration is, however, complex since self-employment can be viewed as both a haven from the paid labour market or as a source of economic growth. Moreover, the nature of selfemployment has changed considerably in recent decades, especially with regards to providing a flexible form of employment for many demographic groups. We investigate the evolving relationship between self-employment and immigration in the UK using recently released microdata from the 2011 Census for England and Wales. Our findings indicate large variations, with high self-employment rates observed for some groups with a long established history of migration to the UK (especially men born in Pakistan) and also for some groups who have arrived more recently (such as from the EU's new member states). We further explore the differences, analyse variations by gender and identify key determining factors. In addition to certain socio-economic characteristics, it is found that migration-related influences, such as English language proficiency and period of arrival in the UK, play an important role for some groups.

JEL Classification: J61, F22, J21

Keywords: self-employment, immigrants, United Kingdom

Corresponding author:

Stephen Drinkwater

University of Roehampton

Business School

London SW15 5SL

United Kingdom

E-mail: stephen.drinkwater@roehampton.ac.uk

\footnotetext{
* The Sample of Anonymised Records has been made available by the Cathie Marsh Centre for Census and Survey Research at the University of Manchester via the UK Data Service. Helpful comments have been received from seminar participants at the University of Roehampton, London. Errors are the responsibility of the authors.
} 


\section{Introduction}

There now exists a fairly well-established international literature on immigration and self-employment/entrepreneurship. Some important findings have emerged including large variations between migrants from different countries of origin, which can be linked to factors such as discrimination in the paid labour market or differences in accessing capital. Entrepreneurs can also provide employment opportunities for others, including for people from their own countries of origin, other countries or for native-born workers. However, in contrast to countries such as the United States (US), where there is already considerable evidence specifically on immigrant self-employment (Borjas, 1986; Sanders and Nee, 1996; Lofstram, 2002), much of the previous research for the United Kingdom (UK) has focused on ethnic minorities, many of whom will be native-born, rather than immigrants. There are some exceptions, including Levie (2007), Clark and Drinkwater (2009) and Jones et al. (2015), but the approach taken in most studies has tended to be from the perspective of self-employment differences across ethnic groups. Given the high levels of immigration to the UK in recent years and that migration flows now emanate from a very diverse set of countries (Vertovec, 2007), it is therefore now timely to fill this gap. Our analysis is further enabled by the release of microdata from the 2011 Census since this dataset contains information not only on recent groups of migrants to the UK but also includes some new migration-specific questions.

In addition to the increased volume of migration to the UK over the past couple of decades, there has also been a shift in countries of origin. In particular, much of the immigration to the UK in the post-war period up until the end of the 1990s originated from New Commonwealth countries, especially from the 
Caribbean, India, Pakistan and Bangladesh. However, migrants to the UK since the turn of this century have increasingly arrived from European countries, especially following the enlargement of the European Union (EU) that took place in May 2004. Continued globalisation more generally has also meant that migrants have started to arrive in the UK from a greater range of countries. The migration flows that have resulted are also likely to have been influenced by new forms of migration such as increased amounts of circular/shorter term migration (Castles et al., 2013). Therefore, given the UK's growing and increasingly diverse immigrant population, previous evidence and perceptions regarding ethnic and immigrant self-employment may now be less relevant. Furthermore, demographic change has continued for the more established immigrant communities and this will have further consequences for their selfemployment decisions (Clark and Drinkwater, 2010a).

Changes in immigration policy can also influence self-employment, possibly through direct or indirect routes. For example, there have been significant policy changes with regards to migrants from countries from outside of the European Economic Area (EEA), especially with regards to the introduction of the Points Based System (PBS) in 2008. The PBS aims to simplify routes of entry to the UK but also to attract particular types of migrants. For example, there is specifically designated sub-category of a tier of the PBS (Tier 1) that relates to overseas entrepreneurs looking to work in the UK. Moreover, there is increasing competition between advanced economies for international entrepreneurs, especially amongst young graduates. For example, UK Trade \& Investment runs the Sirius Programme, which aims to help graduates from overseas with bright ideas set up and grow businesses in the UK. Whilst in the 
context of migration from Europe, although flows from the EU cannot be limited, certain restrictions have previously been imposed on the types of jobs that migrants from new EU member states could do. In particular, migrants from accession countries could enter the UK as self-employees before EU enlargement in May 2004 under the 1994 Europe Agreement, which boosted self-employment rates amongst migrants from these countries (Clark and Drinkwater, 2008). Similarly, migrants from Bulgaria and Romania could work in the UK as selfemployees from when these countries joined the EU in January 2007 until the end of the transitional period in December 2013.

Not only have there been large changes in immigration to the UK in relation to the volume, origin and nature of the migration flows but selfemployment/entrepreneurship has also evolved considerably over the past couple of decades. For example, there has been an increase in sub-contracting, part-time and flexible forms of self-employment (Ajayi-Obe and Parker, 2005; Boheim and Muhlberger, 2009). New types of self-employment have also emerged including false self-employment (Behling and Harvey, 2015) as well as the rise of social entrepreneurship (Doherty et al., 2014). Moreover, there is likely to have been an important gender dimension to these changes since selfemployment can offer more flexible work-life opportunities for women, especially for those with high levels of education (Wellington, 2006).

In this paper we use microdata from the 2011 Census of the Population to undertake a detailed analysis of self-employment for a range of migrant groups across England and Wales. Census microdata provide large samples that enable relatively narrowly defined groups to be examined separately for men and women, some years after the EU enlargements took place. In addition to detailing 
the main differences in the relative concentrations and types of self-employment amongst these groups, we also carry out multivariate analysis using the new migration-related variables that were included in the 2011 Census to ascertain the extent to which these are able to provide further explanations for the observed differences. We focus particularly on the influence that period of arrival and English language ability have on self-employment for different categories of migrants.

\section{Influences on Self-Employment Amongst Immigrants}

There is a long-standing literature on self-employment and immigrants to the US. This applies to both sociological (Light, 1984; Cobas, 1986; Sanders and Nee, 1996; Portes and Zhou, 1999) and economic (Borjas, 1986; Yuengert, 1995; Lofstram, 2002) studies. Such studies have highlighted large differences between immigrants including in identifying the groups that typically have high rates (e.g. migrants from China, Korea and some European countries) and those displaying noticeably lower rates (e.g. migrants from Mexico, Puerto Rico and some African countries). Evidence for the UK is less well established since the literature has tended to focus on ethnic differences, especially amongst Asian groups. This includes studies that have applied quantitative techniques to analyse Census data and large scale government surveys (Basu, 1998; Borooah and Hart, 1999; Clark and Drinkwater, 1998; 2010a,b) or more bespoke surveys (Metcalf et al., 1997; Clark and Drinkwater, 2000; Basu and Altinay, 2002) as well as more detailed (qualitative) analysis on smaller scale data on particular groups (Ram and Deakins, 1996; Ram et al., 2000). As in the US, some Asian groups have high rates of self-employment, especially Pakistani men, whilst rates are relatively 
low for Black Africans and Caribbeans. Differences between groups can, at least partly, be explained by compositional effects in terms of group characteristics associated with either general socio-economic factors or migration-specific influences (Clark and Drinkwater, 2010a).

There now follows a brief review of the influences on self-employment, starting with general socio-economic factors, since these will typically affect different demographic groups in a fairly similar way, before moving onto effects related to migration. We particularly make reference to a recent study by Simeos et al. (2015), who have undertaken a detailed review of the theoretical and empirical literature, covering a wide range of studies and countries, on the determinants of self-employment. ${ }^{1}$ Despite discussing different ways in which socio-economic characteristics can have a positive or negative affect on selfemployment, several clear influences can be identified. ${ }^{2}$ These include that men have far higher rates of self-employment than women and that self-employment increases with age but at a decreasing rate, typically peaking around midworking age. ${ }^{3}$ The presence of family members can also affect the probability of self-employment, with both marriage and children tending to have a positive influence, although there may be differences by gender.

There are other variables that have a more indeterminate effect on selfemployment. For example, education may either increase or decrease selfemployment since more highly qualified individuals will typically have better

\footnotetext{
${ }^{1}$ This study essentially updates and extends that of Le (1999).

${ }^{2}$ Simeos et al. (2015) discuss the different influences that each characteristic has on the probability of self-employment from a theoretical perspective, as well as reviewing the empirical evidence.

${ }^{3}$ Self-employment is also found to increase with experience in the labour market, both in terms of the amount and duration, which is closely related to age. There is, however, some indication that self-employment is becoming increasingly popular amongst older workers, with a growth in the number of 'olderpreneurs' (Fineman, 2014).
} 
opportunities in paid-employment but they also tend to possess greater managerial ability and are better able to identify self-employment opportunities. Thus the overall impact will depend on which of the opposing influences dominates and as a result the effect of education on self-employment is found to vary across countries. Simeos et al. (2015) also note that there is not a large literature on the impact of health, in terms of either illness or disability, and that the empirical evidence on this relationship is far from conclusive, especially as it is affected by measurement and methodological issues.

Several residential variables can affect self-employment. Regional variations are often related to industrial structure and labour market conditions (Georgellis and Wall, 2000) but may also be due to different entrepreneurial traditions. Housing can also influence self-employment decisions, especially through its links with wealth. In particular, owner occupiers can use their houses as collateral to start-up a business and to increase the chances of getting external funding (Simeos et al., 2015). Changes in house prices can also provide a form of windfall investment for existing or potential entrepreneurs (Disney and Gathergood, 2009).

In addition, there are a range of ethnic or immigrant-related influences that have been found to be important for self-employment. Some of these are connected to the factors that have already been discussed such as the clustering of migrant or ethnic groups into particular localities (Clark and Drinkwater, 2010a) and differences in the influence of education on self-employment across groups (Thompson et al., 2010), partly because of variations in levels of discrimination. 
Discrimination. Labour market discrimination can be manifested in the form of either lower wages or higher unemployment and can push (migrant or ethnic) minorities into self-employment (Clark and Drinkwater, 2000). This can occur as a result of the prejudice displayed by employers or co-workers. In addition, consumers may also be discriminating, whereby consumers from majority groups who have prejudices against entrepreneurs from minority groups may only purchase from these groups if they lower their prices (Borjas and Bronars, 1989). There may also be discrimination in the credit market since lenders may be less likely to approve loans or charge higher interest rates to individuals from certain migrant groups (Blanchflower et al., 2003).

Ethnic Enclaves. High concentrations of co-ethnics in specific geographic locations can boost self-employment (Aldrich et al., 1985). This can, for example, result from the provision of ethnic specific goods such as food and clothing and entrepreneurs can also provide jobs for others living in the enclave. Although support for the protected market hypothesis has been found in the US (Lofstram, 2002), there is contrasting evidence for the UK. Clark and Drinkwater (2010a) suggest that this may due to the deprived nature of many enclaves as well as the presence of more intense competition. However, this relationship may alter over time with changes in tastes and technology.

Time since arrival. The number of years that the migrant has resided in the host country may be related to several forms of capital: human, physical and financial. Human capital that is obtained in the host country is likely to be more valuable than that obtained overseas, especially in the paid labour market given that 
employers may fail to recognize certain qualifications and skills. Moreover, the portability of human capital from the migrant's home country is likely to influence the types of jobs that they are able to do in the host country (Friedberg, 2000). It also takes time to accumulate the financial capital that may be necessary to establish a business, implying that migrants may need to spend a period of time in the paid labour market in order to obtain the required financial resources. However, credit constraints could be attenuated for some groups if they have large families or via informal sources of finance from within their communities (Metcalf et al., 1996).

English language skills. Poor language skills in the host country's main language can restrict certain self-employment opportunities but can also encourage them in other circumstances. The latter effect is particularly related to the enclave economy (Evans, 1989). Therefore, it is not clear what the link between language proficiency and self-employment may be, although with a more service-based economy where communication skills are becoming increasingly important then it is likely that some degree of fluency in the language of the host country would be required for successful entry and survival for entrepreneurs.

Culture and Religion. Group-specific cultures can impinge on values, social structures, resources, behavioural patterns and coping strategies, all of which can influence self-employment (Simeos et al., 2015). In addition, selfemployment may be promoted within certain cultures or religions such as amongst Muslims in the UK (Rafiq, 1992) and Protestants across Europe (Nunziata and Rocco, 2011). US studies have also identified a home country 
effect, whereby migrants originating from countries that have high rates of selfemployment are more likely to become self-employed in the host country (e.g. Yuengert, 1995; Fairlie and Meyer, 1996).

Self-employment can also be influenced by immigration policy. Self-employment can be boosted through direct attempts to encourage foreign entrepreneurs such as through Tier 1 of the UK's Points Based System, as well as issuing visas to wealthy individuals from overseas via the investor route (MAC, 2014). ${ }^{4}$ Selfemployment can also be increased in a more indirect way such as has been the case with migration in the lead-up to and then following EU enlargement. In particular, self-employed migrant workers from EUA8 countries were allowed to work in the UK before these countries were admitted into the EU in 2004 and migrants from EUA2 countries could work as self-employees in the UK during the restrictions to mobility from Bulgaria and Romania that were imposed by the UK government between 2007 and 2013.

Ram et al. (2013) and Jones et al. (2015) have begun to explore some of these issues. Ram et al. (2013) discuss some of the policy and research implications of super-diversity in relation migrant businesses in the UK. Jones et al. (2015) use pooled information from the Labour Force Survey, and some of their own survey interviews, to split migrants to the UK into an established group, who arrived in the UK before 2004 (mainly from New Commonwealth countries and China) and new immigrants, who arrived in the UK between 2004 and 2013 (from a more diverse set of countries). They report differences in the distribution of the self-employed in terms of their sector of employment but have

\footnotetext{
${ }^{4}$ The PBS was phased in from 2008 in an attempt by the UK government to simplify immigration from countries outside the EEA. For further details see Dewitt (2012).
} 
relatively small sample sizes, especially for some of the new groups of migrants even though men and women have been combined. We now go onto investigate self-employment amongst migrant groups in England and Wales in more detail using Census microdata. The larger samples also enable some disaggregated multivariate analysis, which is also typically reported separately by gender.

\section{Data and Descriptive Statistics}

All of the analysis in this paper uses the Sample of Anonymised Records (SARs) from the 2011 Census of the Population that took place in England and Wales on March 27th $2011 .^{5}$ The SARs is a 5\% random sample of all Census returns and contains responses to each of the questions on the Census form for over 2.8 million individuals. As a result, it allows us to undertake a detailed investigation of self-employment amongst migrant groups since we can construct fairly narrowly defined groups and investigate the factors that influence selfemployment.

The sample is restricted to the working age population i.e. males and females aged between 16 and 64 and excludes full-time students. Tables 1 and 2 report self-employment rates by gender for a number of different migrant groups. The self-employment rate is calculated as the percentage of employed workers reporting that their main economic activity was self-employment in the week prior to the Census. This was indicated by the respondent ticking the associated box on the Census questionnaire. The tables also report the number of

\footnotetext{
${ }^{5}$ Separate Censuses are undertaken in Scotland and Northern Ireland and these are administered by different statistical agencies. As a result, each agency has different release policies for Census statistics and data, as well as there being some differences in the questions asked. Moreover, England and Wales captures well over 90\% of all immigrants and ethnic minorities in the UK.
} 
individuals in employment for each group (i.e. the denominator used to calculate the self-employment rate). Table 1 presents this information for detailed ethnic groups, separating out individuals who were born in the UK from those born overseas. Table 2 is an analogous table for the main migrant groups. Further details on the construction of these groups can be found in the Appendix.

The self-employment rates for ethnic groups in 2011 share several features with those reported in previous studies (Clark and Drinkwater, 2010b). In particular, the rates are highest for Pakistani men and lowest for the Black groups. There are some differences for women, with the highest rates observed for the Chinese and the lowest for Black Caribbeans. ${ }^{6}$ Some interesting differences for certain ethnic groups emerge if self-employment rates are compared according to whether workers were born in the UK or overseas, with rates tending to be slightly lower for those born in the UK for most ethnic groups but not all. The exceptions include men and women from the Other White and African ethnic groups.

The statistics reported in Table 2 provide further detail on some new migrant groups to the UK, especially in relation to the high levels of migration from other parts of Europe that has occurred over the last couple of decades. The increased importance of these groups can be seen by observing the number of observations, which indicate that migrants from new EU member states were the largest group for both men and women, with in excess of 19,000 and 17,000 workers from these countries present in the sample, respectively. Unsurprisingly, the majority (over $80 \%$ ) of migrants from accession countries

${ }^{6}$ Carter et al. (2015) discuss barriers to establishing businesses for women from ethnic minority groups in the UK. 
arrived after the 2004 enlargement of the EU. This was the only migrant group where the percentage of arrivals after 2003 exceeded the percentage arriving before 2004. To provide some additional context for the self-employment statistics for each of the migrant groups, other key labour market indicators have been reported in Table A1 in the Appendix. More specifically, the table contains activity, employment (including and excluding students) and unemployment rates by gender.

Overall self-employment rates for men are highest for those born in Pakistan - with a very similar figure (36\%) to that for the Pakistani ethnic group, as reported in Table 1. This is considerably higher than the next closest groups, men from Other European countries (28\%) and Ireland (26\%). The lowest rates belong to men from the Old-EU, the Americas (both categories) and India, who all have rates below those of the UK born. The self-employment rate for men arriving after 2003 was lower than earlier arrivals for each of the groups. This was particularly noticeable for the Asian groups, with self-employment rates of less than $10 \%$ observed for more recent male migrants from India and Bangladesh compared to over $25 \%$ for migrants arriving before 2004. Selfemployment rates for women are more concentrated across the migrant groups, ranging only between $9 \%$ and $15 \%$. Women born in the UK and Bangladesh have the lowest rates and the highest rates are observed for women born in Pakistan and other parts of Europe. There are far smaller differences in the selfemployment rates of migrants arriving before and after 2004 in comparison to men. The differences are less than 5 percentage points for most groups, compared to typically over 15 percentage points for men. Moreover, the self- 
employment rates for women from Central and South America arriving after 2003 are higher than for earlier arrivals from these countries.

Table 3 shows the type of self-employment for the main migrant groups by gender. Self-employment is categorized either on a full-time (works more than 30 hours a week) or part-time (works for 30 hours or less a week) basis and either working on their own or employing others (the actual number of others being employed is not recorded). The majority of self-employed men in each of the migrant groups are full-time and do not employ others. This is least apparent for self-employed men born in Bangladesh since almost 50\% of this group work part-time, compared with less than $20 \%$ of men from most other groups. Interestingly, a relatively high proportion of men from Bangladesh (almost 20\%) are in the part-time and employing others category, which is by far the highest amongst any of the groups. ${ }^{7}$ Over a third of self-employed men born in Pakistan work part-time. In contrast, part-time self-employment is a far more important activity for women, accounting for over a half of all self-employed women and in excess of $40 \%$ for all migrant groups. The percentage of women employing others is similar to men, at just over $20 \%$, but is relatively high for some of the (South Asian) groups, especially those born in Bangladesh.

Given that the type of self-employment is related to industrial sector, Table 4 reports self-employment by grouped sectors for migrant groups by gender. There are some notable concentrations including in Transport, Food/Restaurants and Retail for men born in Asia, especially those from Pakistan and Bangladesh. Further information is available by examining more

\footnotetext{
${ }^{7}$ The denominator for this group is relatively small, with only 746 self-employed men born in Bangladesh in the sample, which is the third smallest of the groups reported in Table 3.
} 
disaggregated industrial categories. For example, over $40 \%$ of self-employed men born in Pakistan work in Transportation \& Storage and around two-thirds of self-employed men born in Bangladesh either work in this sector or Accommodation \& Food Service Activities. There are also relatively high sectoral concentrations amongst self-employed women born in Indian, Pakistan, Bangladesh and other parts of Asia in these sectors. More than a half of selfemployed women from New-EU member states work in Health, Education, Administration and Public Services.

\section{Multivariate Analysis}

We now proceed to undertake some regression analysis in order to examine the influence of socio-economic characteristics on self-employment and also to establish whether the extent of the differences across migrant groups. Therefore, the first set of regressions relate to pooled probit models that have been estimated separately for men and women relative to the UK born to determine whether the raw differences identified in the previous section continue to be observed after controlling for other influences. Two empirical specifications have been estimated for each probit model. The basic specification includes a standard set of socio-economic characteristics as explanatory variables, while the augmented specification adds in controls for ethnicity, religion, self-reported health and housing tenure. ${ }^{8}$ Table 5 reports marginal effects, calculated at

\footnotetext{
8 These variables have been included in the augmented specification because of the interrelationships that exist between migrant group, ethnicity and religion, which will influence the estimates for the different migrant groups (relative to the UK born). There are several data issues in connection to health and self-employment, as discussed in Simeos et al. (2015). Housing tenure can have an important effect on self-employment because of the ability to ease credit constraints (Black et al., 1996) but housing tenure is likely to be endogenous in a single equation regression framework (Henley, 2004).
} 
sample means, and associated p-values for the two specifications for men and women. The marginal effects indicate the probability of self-employment for each migrant group relative to the UK born after controlling for observable differences. A positive marginal effect indicates that a particular migrant group is more likely to be self-employed than the UK born after controlling for the explanatory variables that have been included in the particular model. The magnitude of the marginal effect represents the percentage-point differential relative to the UK born. Thus, a marginal effect of 0.05 indicates that the probability of an individual from that group being self-employed is 5 percentage points higher than a comparable person who was born in the UK. The p-value is used to determine the statistical significance of each effect, with a p-value of 0.05 or less suggesting a significant relationship at commonly used levels using a twotailed test. ${ }^{9}$

As shown in Table 2, the highest probability of being self-employed belongs to men born in Pakistan. The estimates in Table 5 reveal that men born in Pakistan have a probability of self-employment that is 15 percentage points higher than the UK born after controlling for a basic set of factors. Migrants from New-EU member states and other parts of Europe are each 7 percentage points more likely to be self-employed. Self-employment is significantly lower for men from several migrant groups (Old-EU, Africa, India, North America \& Caribbean and Central \& South America) than the UK born but the magnitude of the differences are relatively small since they are in the order of 1-3 percentage points. Women from New-EU member states are most likely to be self-employed

${ }^{9} \mathrm{~A}$ full set of results for each of the pooled models using the basic specification appears in Table A2 in the Appendix, along with the means of the explanatory variables. The estimates in this table are generally consistent with the empirical regularities summarised in Simeos et al. (2015). 
after controlling for the basic set of characteristics, followed by migrants from Pakistan and other parts of Europe. The adjusted self-employment probabilities for the remainder of the groups of migrant women are clustered around the UK born, with marginal effects of between -2 and 2 percentage points observed for these groups.

The estimates from the augmented specifications tend to be fairly similar for most groups. The largest differences between the basic and augmented models can be seen for men born in Pakistan - most likely because of the interrelationships between ethnicity, religion and country of birth. This group does not have the highest adjusted probability of self-employment in the augmented specification - this distinction belongs to migrants from New-EU member states. Some of the significant relationships in the basic models also become insignificant in the augmented models such as for male migrants from Africa, North America \& the Caribbean and Central \& South America and female migrants from Ireland and Bangladesh. There is also a change in sign for this latter group, as well as for women from India.

The final two columns in Table 5 report marginal effects and p-values for the probability that a self-employed person (men and women combined) employs others for each migrant group, relative to the UK born. The explanatory variables included in this probit model consist of the controls in the basic specification for estimating the probability of self-employment plus (21) dummy variables for industrial section based on the 2007 Standard Industrial Classification (SIC2007). After controlling for these variables, the probability of having employees is significantly higher than for the UK born for 7 out of the 12 migrant groups. Migrants from Bangladesh, other parts of Asia, India and other 
European countries have the highest probability of employing others. This probability is at least 6 percentage points higher for these groups than it is for the UK born and 15 and 9 percentage points higher for entrepreneurs from Bangladesh and Other parts of Asia respectively. The only migrant groups to have a significantly lower probability of employing others are those born in New-EU member states, Central \& South America and Oceania. However, the difference in the probability of employing others between these groups and the UK born is 4 percentage points or less.

The next set of regression models (reported in Tables 6-8) estimate the probability of self-employment and of employing others separately for four migrant categories. These categories relate to migrants from Old-EU member states (including Ireland), New-EU member states, Other Europe and Outside Europe. These are four policy-relevant categories since they relate to two groups with freedom of movement: one pre-2004 and another since 2004 and two which don't: one from Europe and another from outside. The models allow for the determinants of self-employment, including time of arrival and English language ability, to be investigated separately for the four aggregated migrant groups. Means for the explanatory variables for each category are reported in Table A3 in the Appendix. ${ }^{10}$ This table highlights some interesting differences between the categories including a relatively high proportion of people from immigrant groups in 'other qualifications' category. This is particularly the case for New-EU migrants, where this percentage is in excess of $40 \%$, compared to $6 \%$ for the entire sample, as reported in Table A2. Estimating the models for

\footnotetext{
${ }^{10}$ Some of the dummy variables included in the pooled models, such as for regions and marital status, have been combined because of the relatively small number of observations in some of the categories included in the pooled models for some of the migrant categories.
} 
more categories provides more detailed information e.g. on cohort effects but also results in some relatively small cell sizes for some variables, making the estimates less precise.

In terms of the new migration-specific variables, then male migrants who have been in the UK for longer are far more likely to be self-employed. This is most noticeable for men from outside Europe, where the difference in the probability of self-employment between those arriving before 1990 compared to those after 2007 is around 12 percentage points. The comparable difference for migrants from Old-EU member states is 3 percentage points. The cohort dummies are far less important for male migrants from New-EU member states. In fact, migrants from this group who arrived in the UK between 2001 and 2003 are most likely to be self-employed and have a self-employment rate which is more than 8 percentage points higher than those arriving pre-1990 after controlling for other factors. This accords with evidence provided by Clark and Drinkwater (2008) who report that a high proportion of EUA8 migrants arriving in this period were self-employed because this group were able to enter the labour market through this route prior to the 2004 enlargement. These estimates suggest that this effect has persisted, with large numbers of EUA8 migrants arriving during this period remaining in the UK as self-employed workers.

The results for women migrants with respect to period of arrival in the UK are somewhat different to those for men. Although more recent female arrivals from outside Europe are also significantly less likely to be self-employed, the differentials are far smaller in comparison to their male counterparts (less than a 4 percentage point differential compared to around 12 percentage 
points). Moreover, the cohort dummies are not significantly different from zero for women migrants from the other three categories: Old-EU, New-EU and Other Europe. In fact, women migrants arriving from New-EU member states and other parts of Europe since 2007 are slightly more likely (by around 1-2 percentage points) to be self-employed compared to earlier arrivals. This suggests that the migration policy-induced effects may be slightly different for men and women from these countries or that women arriving in the UK more recently are increasingly exploiting opportunities in self-employment.

There is also some variation in the effect of (English) language proficiency on self-employment. For some categories, such as men from the Old-EU, those with the best (self-defined) English language skills are more likely to be selfemployed. Whilst for some other categories (e.g. women from Outside Europe), those with the best language skills are more likely to be observed in the paid labour market, where they may be able to achieve higher rewards. The estimates for men born in the Old-EU are particularly interesting, with the difference in self-employment rates between men whose main language is English and those who do not speak English well at all being 9 percentage points. Men born in Other Europe and Outside Europe who speak English well are significantly more likely to be self-employed (by 4-5 percentage points after controlling for other influences) than those whose main language is English. There are fewer significant differences for women. In particular, the only significant effects at the 5\% level are observed for women from the Old-EU and Outside Europe. Women from the Old-EU member states who speak English very well have slightly higher adjusted self-employment rates, whilst women from Outside Europe who speak English well and do not speak English well are significantly more likely to be self- 
employed than those whose main language is English. Overall, there are no clear patterns amongst the categories but it certainly does not seem to be the case that self-employment is concentrated amongst migrants with the poorest English language skills.

Tables 6 and 7 also indicate a number of other differences between the migrant groups in relation to the determinants of self-employment. The largest age effects are observed for men from the Old-EU, with age being statistically insignificant for men from other parts of Europe apart from in the 55-64 age group. The influence of age is generally smaller for women. Male graduates from the New-EU, Other Europe and Outside Europe are significantly less likely to be self-employed than those with no qualifications. This is also the case for women migrants from New-EU member states. These findings therefore appear to augment the results with regards to English language ability. There are significant regional effects, especially for New-EU migrants, where adjusted selfemployment rates for men living in London are in excess of 20 percentage points higher than they are in the other four regions. A similar effect can be observed for women from this group but the differentials compared to the other regions are lower at around 12 percentage points. The results with regards to marital status tend to suggest a positive effect of marriage, with significantly positive effects observed for three of the migrant categories for men and women. Workers with dependent children are also more likely to be self-employed, although there are some variations between the groups.

The migration-specific variables also influence the probability of employing others to a varying degree for the different migrant categories, as shown in Table 8. Some of the time of arrival dummies are significant, with a 
clear indication that more recent arrivals are less likely to employ others observed for migrants from the New-EU and from Outside Europe. There are also some significant effects with regards to the English language indicators. Most notably, migrant entrepreneurs from Outside Europe who speak English as a main language are significantly less likely to employ others in comparison to other comparable workers in the four other language categories, with the difference increasing as the level of language proficiency deteriorates. The marginal effect for entrepreneurs from New-EU member states is also significant at the $10 \%$ level but indicates that who do not speak English well are less likely to employ others.

In terms of the other variables, the probability of employing others is highest for the youngest age category amongst migrants from Outside Europe after other characteristics have been controlled for. ${ }^{11}$ Entrepreneurs with degrees from Other Europe are significantly less likely than those without any qualifications to employ others, with some other qualifications dummies significant for migrants from the Old-EU, Other Europe and Outside Europe. There are no significant regional effects. The family variables exert an influence for some of the categories, with an indication that married entrepreneurs with children are more likely to employ others, especially amongst migrants from the Old-EU and Outside Europe. Finally, as expected, part-time entrepreneurs in each of the four groups are significantly less likely to employ others, as are women from all categories apart from the New-EU.

\footnotetext{
11 The percentage employing others does increase with age for all migration categories in the raw data but the age differences are relatively small for people born in the New-EU and Outside Europe.
} 


\section{Conclusion}

The UK experienced an unprecedented increase in immigration in the first decade of the $21^{\text {st }}$ century, especially following EU enlargement in 2004 . As well as affecting public attitudes, these inflows have also influenced patterns of labour market activity including self-employment. In this paper, we have analysed how self-employment varies across different migrant groups, both in terms of its incidence and broad nature. Moreover, the reasons for the observed differences have been examined in some detail, with particular attention being paid to the influence of some new variables that were included in the 2011 Census, especially year of arrival in the UK and English language proficiency.

Our findings suggest that whilst self-employment has remained high for some established migrant groups, especially men born in Pakistan, high rates are also observed for migrants from countries that acceded to the EU in 2004 and 2007. However, the drivers of these high self-employment rates are likely to be quite different. Previous research has indicated that a lack of suitable opportunities in the paid employment, partly due to discrimination, is important for the more established groups (Clark and Drinkwater, 2000; 2010a). In contrast, changes in migration policy including allowing entrepreneurs to access the labour market in the pre-enlargement or transitional periods, as well as the introduction of the PBS for people from non-EEA countries, appear to have been important influences for newer groups of migrants to the UK. Self-employment is also relatively high amongst several groups of women migrants, in comparison to the UK born. Furthermore, there are only small differences between recent and earlier arrivals for some groups, such as for women from Old-EU and NewEU member states. In terms of the effect of explanatory variables, some 
similarities are found amongst the different categories of migrants including in relation to broad regional variations. However, there are also some differences between the categories, including for English language ability and qualifications.

There are also significant differences in the probability of employing others and its determinants. Entrepreneurs from Bangladesh and Other Asian countries are most likely to employ others, whilst the probability of employing others is highest for those with poorer language skills amongst migrants from Outside Europe. These findings are important in the context of needing to expand and diversify the economic base in the UK following the recession, especially given the cuts to the public sector workforce that have already occurred and others that are planned. It may be possible to further investigate this aspect by examining the number of people that are employed by different migrant groups using the Labour Force Survey, although this may be limited to some extent by sample size restrictions.

Taken together, the findings suggest that recent changes in migration policy have had an impact, both directly and more indirectly, on self-employment and entrepreneurship in the UK. This applies both in relation to boosting rates of self-employment, given the high levels observed for some groups of (recent) migrants compared to the UK born - especially amongst women, as well as for the probability of employing others. As a result, there may be scope to further refine and develop migration policy with regards to immigrant entrepreneurship in order to achieve particular targets related to broadening the UK's economic base. More detailed sectoral analysis should be able to shed further light on the extent to which this can be achieved, especially since self-employment may be concentrated in particular low value/skill sectors for some groups. 


\section{References}

Ajayi-Obe, 0. and Parker, S. (2005), "The changing nature of work among the self-employed in the 1990s: Evidence from Britain", Journal of Labor Research, 26, 501-517.

Aldrich, H., Cater, J., Jones, T., McEvoy, D. and Velleman, P. (1985), “Ethnic residential concentration and the protected market hypothesis", Social Forces, 63, 996-1009.

Basu, A. (1998), “An exploration of entrepreneurial activity among Asian small businesses in Britain", Small Business Economics, 10, 313-326.

Basu, A. and Altinay, E. (2002), "The interaction between culture and entrepreneurship in London's immigrant businesses", International Small Business Journal, 20, 371-393.

Behling, F. and Harvey, M. (2015), "The evolution of false self-employment in the British construction industry: A neo-Polanyian account of labour market formation", Work, Employment and Society, forthcoming.

Black, J., De Meza, D. and Jeffreys, D. (1996), "House prices, the supply of collateral and the enterprise economy", Economic Journal, 106, 60-75.

Blanchflower, D., Levine, P. and Zimmermann, D. (2003), "Discrimination in the small-business credit market", Review of Economics and Statistics, 85, 930-943.

Borjas, G. J. (1986), “The self-employment experience of immigrants", Journal of Human Resources, 21, 485-506.

Borjas, G. J. and Bronars, S. (1989), "Customer discrimination and selfemployment", Journal of Political Economy, 97, 581-605. 
Borooah, V. K. and Hart, M. (1999), “Factors affecting self-employment among Indian and Black Caribbean men in Britain", Small Business Economics, 13, 111-129.

Caliendo, M., Fossen, F. M and Kritikos, A. S. (2009), "Risk attitudes of nascent entrepreneurs - New evidence from an experimentally validated survey", Small Business Economics, 32, 153-167.

Carter, S., Mwaura, S., Ram, M., Trehan, K. and Jones, T. (2015), "Barriers to ethnic minority and women's enterprise: Existing evidence, policy tensions and unsettled questions", International Small Business Journal, 33, 49-69.

Castles, S., De Haas, H. and Miller, M. J. (2013), The Age of Migration: International Population Movements in the Modern World, $5^{\text {th }}$ Edition, Palgrave Macmillan, Basingstoke.

Clark, K. and Drinkwater, S. (1998), "Ethnicity and self-employment in Britain”, Oxford Bulletin of Economics and Statistics, 60, 383-407.

Clark, K. and Drinkwater, S. (2000), "Pushed in or pulled out? Self-employment among ethnic minorities in England and Wales", Labour Economics, 7, 603-628.

Clark, K. and Drinkwater, S. (2008), “The labour-market performance of recent migrants", Oxford Review of Economic Policy, 24, 495-516.

Clark, K. and Drinkwater, S. (2010a), "Patterns of ethnic self-employment in time and space: Evidence from British Census microdata", Small Business Economics, 34, 323-338.

Clark, K. and Drinkwater, S. (2010b), "Recent trends in minority ethnic entrepreneurship in Britain", International Small Business Journal, 28, 136-146. 
Cobas, J. A. (1986), "Paths to self-employment among immigrants: An analysis of four interpretations", Sociological Perspectives, 29, 101-120.

Devitt, C. (2012), “Labour migration governance in contemporary Europe. The UK case”, Fieri Working Paper, April.

Disney, R. and Gathergood, J. (2009), “Housing wealth, liquidity constraints and self-employment", Labour Economics, 16, 79-88.

Doherty, B., Haugh, H. and Lyon, F. (2014), "Social enterprises as hybrid organizations: A review and research agenda", International Journal of Management Reviews, 16, 417-436.

Evans, M. D. R. (1989), “Immigrant entrepreneurship: Effects of ethnic market size and isolated labor market pool", American Sociological Review, 54, $950-962$.

Fairlie, R. W. and Meyer, B. D. (1996), "Ethnic and racial self-employment differences and possible explanations”, Journal of Human Resources, 31, 757-793.

Fineman, S. (2014), “Age matters”, Organization Studies, 35, 1719-1723.

Friedberg, R. (2000), “You can't take it with you? Immigrant assimilation and the portability of human capital", Journal of Labor Economics, 18, 221-251.

Georgellis, Y. and Wall, H. J. (2000), "What makes a region entrepreneurial? Evidence from Britain", The Annals of Regional Science, 34, 385-403.

Henley, A. (2004), "Self-employment status: The role of state dependence and initial circumstances", Small Business Economics, 22, 67-82.

Jones, T., Ram, M., Li, Y., Edwards, P. and Villares, M. (2015), "Super-diverse Britain and new migrant enterprises", IRiS Working Paper Series No. 8, University of Birmingham. 
Le, A. T. (1999), "Empirical studies of self-employment", Journal of Economic Surveys, 13, 382-416.

Levie, J. (2007), "Immigration, in-migration, ethnicity and entrepreneurship in the United Kingdom", Small Business Economics, 28, 143-169.

Light, I. (1984), "Immigrant and ethnic enterprise in North America”, Ethnic and Racial Studies, 7, 195-216.

Lofstrom, M. (2002), "Labor market assimilation and the self-employment decision of immigrant entrepreneurs", Journal of Population Economics, 15, 191-222.

MAC (2014), Tier 1 Investor Route: Investment Thresholds and Economic Benefits, Migration Advisory Committee, Home Office, London.

Metcalf, H., Modood, T. and Virdee, S. (1996), Asian Self-Employment: The Interaction of Culture and Economics, Policy Studies Institute, London.

Nunziata, L. and Rocco, L. (2011), “The implications of cultural background on labour market choices: The case of religion and entrepreneurship", IZA Discussion Paper No. 6114.

Portes, A. and Zhou, M. (1999), "Entrepreneurship and economic progress in the Nineties: A comparative analysis of immigrants and African Americans" in F. Bean and S. Bell-Rose (eds), Immigration and Opportunity: Race, Ethnicity, and Employment in the United States, Russell Sage Foundation, New York.

Rafiq, M. (1992), “Ethnicity and enterprise: A comparison of Muslim and nonMuslim owned Asian businesses in Britain", Journal of Ethnic and Migration Studies, 19, 43-60. 
Ram, M. and Deakins, D. (1996), "African-Caribbeans in business", Journal of Ethnic and Migration Studies, 22, 67-84.

Ram, M., Sanghera, B., Abbas, T., Barlow, G. and Jones, T. (2000), “Ethnic minority business in comparative perspective: The case of the independent restaurant sector", Journal of Ethnic and Migration Studies, 26, 495-510.

Ram, M., Jones, T., Edwards, P., Kiselinchev, A., Muchenje, L. and Woldesenbet, K. (2013), "Engaging with super-diversity: New migrant businesses and the research-policy nexus", International Small Business Journal, 31, 337-356.

Sanders, J. M. and Nee, V. (1996), "Immigrant self-employment: The family as social capital and the value of human capital", American Sociological Review, 61, 231-249.

Simoes, N., Crespo, N. and Moreira, S. B. (2015), "Individual determinants of selfemployment entry: What do we really know?", Journal of Economic Surveys, forthcoming.

Thompson, P, Jones-Evans, D. and Wong, C. (2010), "Education and entrepreneurial activity: A comparison of White and South Asian men", International Small Business Journal, 28, 147-162.

Vertovec, S. (2007), "Super-diversity and its implications", Ethnic and Racial Studies, 30, 1024-1054.

Wellington, A. (2006), "Self-employment: The new solution for balancing family and career?", Labour Economics, 13, 357-386.

Yuengert, A. M. (1995), "Testing hypotheses of immigrant self-employment," Journal of Human Resources, 30, 194-204. 
Table 1: Self-Employment Rates by Ethnic Group and Country of Birth (Whether Born in UK), 2011

\begin{tabular}{|c|c|c|c|c|c|c|c|c|c|c|c|c|}
\hline & \multicolumn{6}{|c|}{ Males } & \multicolumn{6}{|c|}{ Females } \\
\hline & \multicolumn{2}{|c|}{ All } & \multicolumn{2}{|c|}{ UK Born } & \multicolumn{2}{|c|}{ Foreign Born } & \multicolumn{2}{|c|}{ All } & \multicolumn{2}{|c|}{ UK Born } & \multicolumn{2}{|c|}{ Foreign Born } \\
\hline & Rate & $\mathbf{N}$ & Rate & $\mathbf{N}$ & Rate & $\mathbf{N}$ & Rate & $\mathbf{N}$ & Rate & $\mathbf{N}$ & Rate & $\mathbf{N}$ \\
\hline White: UK & 19.6 & 532,145 & 19.6 & 519,237 & 21.1 & 12,908 & 9.3 & 474,070 & 9.2 & 462,199 & 13.8 & 11,871 \\
\hline White: Irish & 24.6 & 6,301 & 22.0 & 2,680 & 26.6 & 3,621 & 9.7 & 5,828 & 9.5 & 2,189 & 9.8 & 3,639 \\
\hline White: Gypsy or Irish & 38.2 & 421 & 40.1 & 354 & 28.4 & 67 & 20.2 & 262 & 19.1 & 230 & 28.1 & 32 \\
\hline White: Other White & 21.9 & 37,742 & 23.9 & 2,575 & 21.7 & 35,167 & 13.9 & 35,917 & 14.1 & 2,252 & 13.9 & 33,665 \\
\hline White and Black Caribbean & 17.1 & 2,881 & 16.5 & 2,608 & 22.3 & 273 & 6.8 & 2,845 & 6.0 & 2,595 & 15.2 & 250 \\
\hline White and Black African & 16.3 & 1,137 & 15.2 & 520 & 17.2 & 617 & 9.9 & 1,087 & 10.2 & 547 & 9.6 & 540 \\
\hline White and Asian Mixed & 19.1 & 2,589 & 17.1 & 1,842 & 24.1 & 747 & 11.1 & 2,248 & 9.9 & 1,673 & 14.8 & 575 \\
\hline Other Mixed & 19.6 & 2,312 & 18.9 & 1,241 & 20.5 & 1,071 & 10.6 & 2,308 & 9.4 & 1,258 & 12.0 & 1,050 \\
\hline Indian & 19.8 & 19,050 & 18.6 & 6,319 & 20.4 & 12,731 & 10.0 & 15,031 & 8.2 & 5,628 & 11.1 & 9,403 \\
\hline Pakistani & 31.9 & 11,079 & 24.2 & 3,915 & 36.1 & 7,164 & 10.6 & 4,911 & 7.4 & 2,701 & 14.5 & 2,210 \\
\hline Bangladeshi & 20.5 & 4,240 & 12.6 & 988 & 22.9 & 3,252 & 7.3 & 1,813 & 4.9 & 797 & 9.3 & 1,016 \\
\hline Chinese & 23.2 & 3,906 & 16.6 & 850 & 25.1 & 3,056 & 16.4 & 4,032 & 9.0 & 732 & 18.0 & 3,300 \\
\hline Other Asian & 19.1 & 9,238 & 17.3 & 1,157 & 19.3 & 8,081 & 10.7 & 8,160 & 8.3 & 998 & 11.0 & 7,162 \\
\hline African & 15.9 & 8,734 & 18.7 & 1,099 & 15.5 & 7,635 & 8.1 & 8,558 & 9.6 & 1,282 & 7.9 & 7,276 \\
\hline Caribbean & 16.4 & 5,802 & 14.5 & 3,664 & 19.6 & 2,138 & 6.1 & 7,173 & 6.0 & 4,473 & 6.2 & 2,700 \\
\hline Other Black & 16.6 & 2,330 & 15.9 & 1,368 & 17.7 & 962 & 9.0 & 2,074 & 7.7 & 1,281 & 11.1 & 793 \\
\hline Other: Arab & 22.0 & 2,300 & 19.4 & 237 & 22.3 & 2,063 & 14.2 & 819 & 14.6 & 137 & 14.1 & 682 \\
\hline Other: Any other group & 22.6 & 4,311 & 20.3 & 880 & 23.2 & 3,431 & 13.1 & 2,790 & 10.9 & 678 & 13.8 & 2,112 \\
\hline All Ethnic Groups & 20.0 & 656,518 & 19.6 & 551,534 & 22.1 & 104,984 & 9.6 & 579,926 & 9.1 & 491,650 & 12.5 & 88,276 \\
\hline
\end{tabular}

Notes: The self-employment rate is the self-employed expressed as a percentage of total employment for each group. $\mathrm{N}$ is the denominator and relates to the number of individuals in employment (excluding economically active full-time students). 
Table 2: Self-Employment Rates by Country/Region of Birth, 2011

\begin{tabular}{|c|c|c|c|c|c|c|c|c|c|c|c|c|}
\hline & \multicolumn{6}{|c|}{ Males } & \multicolumn{6}{|c|}{ Females } \\
\hline & \multicolumn{2}{|c|}{ All } & \multicolumn{2}{|c|}{$\begin{array}{c}\text { Arrived } \\
\text { Pre-2004 }\end{array}$} & \multicolumn{2}{|c|}{$\begin{array}{c}\text { Arrived } \\
2004-11 \\
\end{array}$} & \multicolumn{2}{|r|}{ All } & \multicolumn{2}{|c|}{$\begin{array}{c}\text { Arrived } \\
\text { Pre-2004 }\end{array}$} & \multicolumn{2}{|c|}{$\begin{array}{l}\text { Arrived } \\
2004-11\end{array}$} \\
\hline & Rate & $\mathbf{N}$ & Rate & $\mathbf{N}$ & Rate & $\mathbf{N}$ & Rate & $\mathbf{N}$ & Rate & $\mathbf{N}$ & Rate & $\mathbf{N}$ \\
\hline UK & 19.6 & 551,534 & - & - & - & - & 9.1 & 491,650 & - & - & - & - \\
\hline Ireland & 26.1 & 3,919 & 27.9 & 3,137 & 18.9 & 782 & 9.7 & 3,915 & 10.4 & 3,208 & 6.4 & 707 \\
\hline Old-EU & 16.5 & 12,439 & 19.3 & 7,796 & 11.7 & 4,643 & 12.2 & 12,325 & 13.2 & 8,250 & 10.2 & 4,075 \\
\hline New-EU & 24.1 & 19,029 & 39.1 & 3,302 & 21.0 & 15,727 & 14.1 & 17,800 & 17.7 & 3,958 & 13.1 & 13,842 \\
\hline Other Europe & 27.6 & 4,202 & 29.8 & 2,926 & 22.5 & 1,276 & 15.1 & 3,159 & 15.6 & 2,129 & 13.9 & 1,030 \\
\hline Africa & 19.7 & 18,578 & 22.0 & 13,975 & 12.9 & 4,603 & 10.7 & 15,977 & 11.3 & 12,408 & 8.7 & 3,569 \\
\hline India & 18.7 & 10,241 & 26.0 & 5,855 & 8.9 & 4,386 & 10.7 & 7,283 & 12.9 & 4,857 & 6.2 & 2,426 \\
\hline Pakistan & 36.4 & 7,119 & 42.7 & 5,174 & 19.7 & 1,945 & 15.4 & 2,186 & 15.8 & 1,743 & 13.5 & 443 \\
\hline Bangladesh & 23.2 & 3,221 & 26.3 & 2,597 & 9.9 & 624 & 9.1 & 1,035 & 9.3 & 843 & 8.3 & 192 \\
\hline Other Asia & 21.9 & 14,823 & 26.1 & 10,549 & 11.5 & 4,274 & 13.6 & 12,551 & 15.2 & 8,574 & 10.1 & 3,977 \\
\hline North America \& Caribbean & 18.8 & 5,802 & 22.2 & 4,003 & 11.3 & 1,799 & 12.1 & 6,382 & 12.6 & 4,786 & 10.6 & 1,596 \\
\hline Central \& South America & 18.2 & 2,200 & 19.4 & 1,198 & 16.9 & 1,002 & 14.2 & 2,368 & 13.4 & 1,403 & 15.2 & 965 \\
\hline Oceania & 20.8 & 3,411 & 23.3 & 1,894 & 17.6 & 1,517 & 13.0 & 3,295 & 15.9 & 1,715 & 9.8 & 1,580 \\
\hline All Countries of Birth & 20.0 & 656,518 & & & & & 9.6 & 579,926 & & & & \\
\hline
\end{tabular}

Note: See notes to Table 1. 
Table 3: Type of Self-Employment by Country/Region of Birth, 2011

\begin{tabular}{|c|c|c|c|c|c|c|c|c|}
\hline & \multicolumn{4}{|c|}{ Males } & \multicolumn{4}{|c|}{ Females } \\
\hline & $\begin{array}{l}\text { \% PT } \\
\text { with }\end{array}$ & $\begin{array}{l}\text { \% FT } \\
\text { with }\end{array}$ & $\begin{array}{c}\text { \% PT } \\
\text { own }\end{array}$ & $\begin{array}{c}\text { \% FT } \\
\text { own }\end{array}$ & $\begin{array}{l}\text { \% PT } \\
\text { with }\end{array}$ & $\begin{array}{l}\text { \% FT } \\
\text { with }\end{array}$ & $\begin{array}{c}\text { \% PT } \\
\text { own }\end{array}$ & $\begin{array}{l}\% \text { FT } \\
\text { own }\end{array}$ \\
\hline UK & 1.7 & 20.9 & 15.8 & 61.6 & 6.8 & 14.0 & 45.0 & 34.2 \\
\hline Ireland & 2.2 & 25.6 & 12.4 & 59.9 & 5.8 & 18.2 & 35.3 & 40.8 \\
\hline Old-EU & 1.9 & 23.5 & 17.1 & 57.6 & 4.6 & 10.5 & 48.3 & 36.5 \\
\hline New-EU & 2.2 & 16.2 & 15.2 & 66.4 & 5.3 & 8.6 & 53.9 & 32.2 \\
\hline Other Europe & 8.3 & 26.6 & 19.1 & 46.0 & 7.1 & 10.7 & 43.5 & 38.7 \\
\hline Africa & 3.5 & 26.8 & 18.9 & 50.8 & 6.7 & 17.2 & 38.3 & 37.8 \\
\hline India & 4.3 & 31.4 & 15.3 & 49.0 & 10.1 & 21.1 & 31.8 & 37.0 \\
\hline Pakistan & 7.8 & 19.2 & 32.8 & 40.2 & 13.1 & 13.7 & 42.6 & 30.7 \\
\hline Bangladesh & 19.2 & 26.0 & 28.4 & 26.4 & 23.4 & 16.0 & 38.3 & 22.3 \\
\hline Other Asia & 6.8 & 34.3 & 18.8 & 40.0 & 10.5 & 23.8 & 32.2 & 33.5 \\
\hline North America \& Caribbean & 1.4 & 21.4 & 18.5 & 58.8 & 3.9 & 11.5 & 45.5 & 39.0 \\
\hline Central \& South America & 3.2 & 15.0 & 23.4 & 58.4 & 7.5 & 9.3 & 48.1 & 35.2 \\
\hline Oceania & 1.3 & 19.2 & 15.1 & 64.4 & 5.1 & 8.4 & 36.2 & 50.2 \\
\hline All Countries of Birth & 2.2 & 21.5 & 16.4 & 59.9 & 6.9 & 14.1 & 44.5 & 34.6 \\
\hline
\end{tabular}

Notes: "FT" relates to full-time self-employed (those working more than 30 hours a week in their main job) and "PT" relates to part-time employment (those working 30 or less hours a week). "With" relates to those employing others and "own" relates to those not employing others. 
Table 4: Sectoral Distribution of Self-Employment by Country/Region of Birth, 2011

\begin{tabular}{|c|c|c|c|c|c|c|c|c|}
\hline & \multicolumn{4}{|c|}{ Males } & \multicolumn{4}{|c|}{ Females } \\
\hline & $\begin{array}{c}\% \\
\text { Sectors } \\
\text { A-E }\end{array}$ & $\begin{array}{c}\% \\
\text { Sector } \\
\text { F }\end{array}$ & $\begin{array}{c}\text { \% } \\
\text { Sectors } \\
\text { G-I }\end{array}$ & $\begin{array}{c}\% \% \\
\text { Sectors } \\
\text { J-U }\end{array}$ & $\begin{array}{c}\% \% \\
\text { Sectors } \\
\text { A-F }\end{array}$ & $\begin{array}{c}\text { \% } \\
\text { Sectors } \\
\text { G-I }\end{array}$ & $\begin{array}{c}\% \\
\text { Sectors } \\
\text { N-Q }\end{array}$ & $\begin{array}{c}\% \% \\
\text { Sectors J-M } \\
\text { and R-U }\end{array}$ \\
\hline UK & 11.1 & 31.4 & 20.6 & 36.9 & 10.2 & 20.0 & 33.0 & 36.7 \\
\hline Ireland & 6.1 & 39.3 & 15.7 & 39.0 & 9.7 & 17.4 & 33.2 & 39.7 \\
\hline Old-EU & 6.3 & 16.7 & 21.4 & 55.7 & 6.8 & 15.8 & 36.3 & 41.1 \\
\hline New-EU & 4.6 & 55.2 & 19.5 & 20.8 & 8.3 & 16.2 & 51.4 & 24.1 \\
\hline Other Europe & 4.4 & 25.3 & 40.0 & 30.3 & 7.6 & 18.1 & 31.3 & 43.1 \\
\hline Africa & 5.0 & 13.6 & 32.8 & 48.6 & 6.0 & 23.7 & 37.3 & 33.1 \\
\hline India & 6.4 & 14.3 & 39.0 & 40.3 & 5.2 & 41.6 & 30.2 & 23.1 \\
\hline Pakistan & 5.0 & 6.3 & 66.2 & 22.6 & 10.1 & 39.9 & 32.4 & 17.6 \\
\hline Bangladesh & 3.5 & 3.6 & 74.4 & 18.5 & 8.5 & 36.2 & 33.0 & 22.3 \\
\hline Other Asia & 4.5 & 9.0 & 49.9 & 36.5 & 5.7 & 35.7 & 27.0 & 31.7 \\
\hline North America \& Caribbean & 6.1 & 20.4 & 15.2 & 58.3 & 6.7 & 12.8 & 32.0 & 48.4 \\
\hline Central \& South American & 3.2 & 19.5 & 27.2 & 50.1 & 5.4 & 17.3 & 37.9 & 39.4 \\
\hline Oceania & 5.8 & 18.8 & 11.7 & 63.7 & 3.7 & 11.0 & 32.9 & 52.3 \\
\hline All Countries of Birth & 10.0 & 29.9 & 23.2 & 36.9 & 9.6 & 20.6 & 33.9 & 36.0 \\
\hline
\end{tabular}

Notes: Sectors have been constructed according to SIC2007. Sectors A-E are primary \& secondary industries, Sector F is Construction, Sectors G-I are Retail, Food/Restaurants \& Transport and Sectors J-U are Other Services. The sectors for females are slightly different to those for males, with Sectors A-F combined into one category and Other Services split into two. Sectors N-Q relate to Health, Education, Administration and Public Services. 
Table 5: Estimates of Self-Employment Probabilities for Country/Region of Birth

\begin{tabular}{|c|c|c|c|c|c|c|c|c|c|c|}
\hline & \multicolumn{4}{|c|}{ Males - Self-Employed } & \multicolumn{4}{|c|}{ Females - Self-Employed } & \multirow{2}{*}{\multicolumn{2}{|c|}{$\begin{array}{c}\text { All - With } \\
\text { Employees }\end{array}$}} \\
\hline & \multicolumn{2}{|c|}{ Basic } & \multicolumn{2}{|c|}{ Augmented } & \multicolumn{2}{|c|}{ Basic } & \multicolumn{2}{|c|}{ Augmented } & & \\
\hline & M.E. & p-value & M.E. & p-value & M.E. & p-value & M.E. & p-value & M.E. & p-value \\
\hline Ireland & 0.036 & 0.000 & 0.021 & 0.014 & -0.013 & 0.002 & -0.005 & 0.393 & 0.047 & 0.000 \\
\hline Old-EU & -0.031 & 0.000 & -0.031 & 0.000 & 0.017 & 0.000 & 0.008 & 0.008 & -0.009 & 0.212 \\
\hline New-EU & 0.070 & 0.000 & 0.084 & 0.000 & 0.063 & 0.000 & 0.062 & 0.000 & -0.019 & 0.001 \\
\hline Other Europe & 0.070 & 0.000 & 0.049 & 0.000 & 0.038 & 0.000 & 0.026 & 0.000 & 0.061 & 0.000 \\
\hline Africa & -0.017 & 0.000 & -0.002 & 0.555 & -0.005 & 0.015 & 0.010 & 0.002 & 0.038 & 0.000 \\
\hline India & -0.015 & 0.000 & -0.027 & 0.000 & 0.000 & 0.942 & 0.004 & 0.380 & 0.067 & 0.000 \\
\hline Pakistan & 0.152 & 0.000 & 0.054 & 0.000 & 0.050 & 0.000 & 0.053 & 0.000 & 0.020 & 0.015 \\
\hline Bangladesh & 0.004 & 0.575 & 0.027 & 0.064 & -0.015 & 0.050 & 0.014 & 0.369 & 0.147 & 0.000 \\
\hline Other Asia & 0.010 & 0.003 & 0.018 & 0.000 & 0.022 & 0.000 & 0.017 & 0.000 & 0.094 & 0.000 \\
\hline North Am. \& Caribbean & -0.029 & 0.000 & -0.008 & 0.142 & 0.003 & 0.327 & 0.020 & 0.000 & -0.016 & 0.089 \\
\hline Central \& South America & -0.028 & 0.000 & -0.014 & 0.111 & 0.022 & 0.000 & 0.026 & 0.000 & -0.036 & 0.017 \\
\hline Oceania & 0.013 & 0.058 & 0.013 & 0.068 & 0.021 & 0.000 & 0.012 & 0.026 & -0.030 & 0.013 \\
\hline Pseudo R-Squared & \multicolumn{2}{|c|}{0.034} & \multicolumn{2}{|c|}{0.037} & \multicolumn{2}{|c|}{0.034} & \multicolumn{2}{|c|}{0.040} & \multicolumn{2}{|c|}{0.081} \\
\hline Number of Observations & \multicolumn{2}{|c|}{656,518} & \multicolumn{2}{|c|}{652,447} & \multicolumn{2}{|c|}{579,926} & \multicolumn{2}{|c|}{578,485} & \multicolumn{2}{|c|}{186,883} \\
\hline
\end{tabular}

Notes: Augmented specification is the basic specification plus controls for ethnicity, religion, self-reported health and housing tenure.

Dependent children not applicable has been included as a control in both specifications. Ethnicity, religion and tenure not applicable have been removed from the augmented specification but religion not stated has been included as a category. 
Table 6: Estimates of the Probability of Self-Employment for Men by

Migrant Category

\begin{tabular}{|c|c|c|c|c|c|c|c|c|}
\hline & \multicolumn{2}{|c|}{ Old-EU } & \multicolumn{2}{|c|}{ New-EU } & \multicolumn{2}{|c|}{ Other Europe } & \multicolumn{2}{|c|}{ Outside Europe } \\
\hline & M.E. & p-value & M.E. & p-value & M.E. & p-value & M.E. & p-value \\
\hline Arrived in 1990s & 0.007 & 0.439 & 0.030 & 0.188 & -0.023 & 0.284 & -0.041 & 0.000 \\
\hline Arrived 2000-3 & -0.024 & 0.046 & 0.083 & 0.000 & -0.070 & 0.005 & -0.076 & 0.000 \\
\hline Arrived 2004-6 & -0.024 & 0.044 & -0.033 & 0.068 & -0.062 & 0.018 & -0.110 & 0.000 \\
\hline Arrived 2007-9 & -0.030 & 0.009 & 0.003 & 0.893 & -0.078 & 0.002 & -0.120 & 0.000 \\
\hline Arrived 2010-11 & -0.030 & 0.021 & 0.004 & 0.837 & -0.099 & 0.001 & -0.117 & 0.000 \\
\hline Speaks English very well & -0.040 & 0.000 & -0.016 & 0.258 & 0.015 & 0.443 & -0.001 & 0.799 \\
\hline Speaks English well & -0.022 & 0.034 & 0.006 & 0.682 & 0.051 & 0.012 & 0.037 & 0.000 \\
\hline Does not speak English well & -0.064 & 0.000 & -0.001 & 0.956 & -0.009 & 0.765 & -0.020 & 0.007 \\
\hline $\begin{array}{l}\text { Does not speak English } \\
\text { at all well }\end{array}$ & -0.092 & 0.041 & 0.013 & 0.621 & 0.004 & 0.969 & -0.055 & 0.019 \\
\hline Aged 25-34 & 0.144 & 0.000 & 0.050 & 0.000 & 0.060 & 0.066 & 0.088 & 0.000 \\
\hline Aged 35-44 & 0.204 & 0.000 & 0.103 & 0.000 & 0.051 & 0.152 & 0.132 & 0.000 \\
\hline Aged 45-54 & 0.302 & 0.000 & 0.134 & 0.000 & 0.077 & 0.056 & 0.157 & 0.000 \\
\hline Aged 55-64 & 0.369 & 0.000 & 0.149 & 0.000 & 0.135 & 0.009 & 0.192 & 0.000 \\
\hline GCSEs or equivalent & -0.033 & 0.006 & 0.000 & 0.969 & -0.036 & 0.128 & -0.040 & 0.000 \\
\hline A Levels/Apprenticeship & 0.006 & 0.630 & -0.019 & 0.157 & -0.034 & 0.232 & -0.049 & 0.000 \\
\hline Degree & -0.043 & 0.000 & -0.078 & 0.000 & -0.120 & 0.000 & -0.066 & 0.000 \\
\hline Other qualification & -0.009 & 0.491 & 0.004 & 0.699 & -0.011 & 0.605 & -0.013 & 0.025 \\
\hline South/East England & -0.045 & 0.000 & -0.224 & 0.000 & -0.032 & 0.066 & -0.026 & 0.000 \\
\hline Midlands & -0.048 & 0.000 & -0.238 & 0.000 & -0.095 & 0.000 & -0.014 & 0.004 \\
\hline North England & -0.064 & 0.000 & -0.242 & 0.000 & -0.076 & 0.000 & 0.012 & 0.011 \\
\hline Wales/South West & -0.038 & 0.000 & -0.217 & 0.000 & 0.004 & 0.875 & -0.024 & 0.000 \\
\hline Married/Civil Partnership & 0.000 & 0.986 & 0.051 & 0.000 & 0.022 & 0.292 & 0.028 & 0.000 \\
\hline Widowed/Divorced/Separated & 0.000 & 0.984 & 0.052 & 0.000 & 0.062 & 0.024 & 0.030 & 0.000 \\
\hline 1 dependent child & 0.007 & 0.498 & 0.005 & 0.587 & 0.033 & 0.136 & -0.004 & 0.465 \\
\hline 2 dependent children & 0.029 & 0.009 & 0.019 & 0.113 & 0.024 & 0.289 & 0.008 & 0.139 \\
\hline $3+$ dependent children & 0.040 & 0.017 & 0.061 & 0.007 & 0.044 & 0.193 & 0.073 & 0.000 \\
\hline Dependent Children N/A & 0.014 & 0.087 & -0.009 & 0.259 & 0.043 & 0.049 & -0.003 & 0.569 \\
\hline Pseudo R-Squared & \multicolumn{2}{|c|}{0.051} & \multicolumn{2}{|c|}{0.178} & \multicolumn{2}{|c|}{0.033} & \multicolumn{2}{|c|}{0.052} \\
\hline Number of Observations & \multicolumn{2}{|c|}{16,358} & \multicolumn{2}{|c|}{19,029} & \multicolumn{2}{|c|}{4,202} & \multicolumn{2}{|c|}{65,395} \\
\hline
\end{tabular}

Notes: Default categories are arrived before 1990, main language is English, aged 16-24, no qualifications, lives in London, single and no dependent children. 
Table 7: Estimates of the Probability of Self-Employment for Women by

Migrant Category

\begin{tabular}{|c|c|c|c|c|c|c|c|c|}
\hline & \multicolumn{2}{|c|}{ Old-EU } & \multicolumn{2}{|c|}{ New-EU } & \multicolumn{2}{|c|}{ Other Europe } & \multicolumn{2}{|c|}{ Outside Europe } \\
\hline & M.E. & p-value & M.E. & p-value & M.E. & p-value & M.E. & p-value \\
\hline Arrived in 1990s & 0.000 & 0.961 & -0.003 & 0.845 & -0.035 & 0.045 & -0.011 & 0.004 \\
\hline Arrived 2000-3 & -0.005 & 0.641 & -0.003 & 0.835 & -0.032 & 0.139 & -0.043 & 0.000 \\
\hline Arrived 2004-6 & 0.005 & 0.649 & -0.021 & 0.106 & -0.037 & 0.078 & -0.037 & 0.000 \\
\hline Arrived 2007-9 & 0.004 & 0.696 & 0.013 & 0.383 & -0.004 & 0.872 & -0.034 & 0.000 \\
\hline Arrived 2010-11 & 0.010 & 0.451 & 0.018 & 0.298 & 0.007 & 0.831 & -0.024 & 0.000 \\
\hline Speaks English very well & 0.013 & 0.047 & -0.006 & 0.524 & -0.028 & 0.055 & -0.011 & 0.006 \\
\hline Speaks English well & 0.012 & 0.252 & 0.016 & 0.100 & -0.012 & 0.517 & 0.015 & 0.001 \\
\hline Does not speak English well & -0.011 & 0.598 & 0.019 & 0.117 & 0.002 & 0.959 & 0.036 & 0.000 \\
\hline $\begin{array}{l}\text { Does not speak English at } \\
\text { all well }\end{array}$ & -0.046 & 0.301 & 0.005 & 0.817 & -0.009 & 0.905 & 0.004 & 0.855 \\
\hline Aged 25-34 & 0.027 & 0.042 & 0.010 & 0.233 & 0.043 & 0.179 & 0.034 & 0.000 \\
\hline Aged 35-44 & 0.088 & 0.000 & 0.043 & 0.000 & 0.056 & 0.108 & 0.061 & 0.000 \\
\hline Aged 45-54 & 0.125 & 0.000 & 0.044 & 0.002 & 0.122 & 0.006 & 0.077 & 0.000 \\
\hline Aged 55-64 & 0.162 & 0.000 & 0.091 & 0.000 & 0.159 & 0.005 & 0.091 & 0.000 \\
\hline GCSEs or equivalent & -0.036 & 0.000 & -0.025 & 0.004 & 0.073 & 0.111 & -0.037 & 0.000 \\
\hline A Levels/Apprenticeship & 0.004 & 0.746 & -0.036 & 0.000 & 0.160 & 0.004 & -0.021 & 0.001 \\
\hline Degree & 0.016 & 0.144 & -0.035 & 0.000 & 0.102 & 0.001 & -0.008 & 0.167 \\
\hline Other qualification & 0.003 & 0.809 & -0.005 & 0.526 & 0.208 & 0.000 & 0.002 & 0.731 \\
\hline South/East England & -0.028 & 0.000 & -0.122 & 0.000 & -0.013 & 0.384 & -0.003 & 0.342 \\
\hline Midlands & -0.048 & 0.000 & -0.125 & 0.000 & -0.079 & 0.000 & -0.023 & 0.000 \\
\hline North England & -0.041 & 0.000 & -0.122 & 0.000 & -0.077 & 0.000 & -0.002 & 0.708 \\
\hline Wales/South West & -0.005 & 0.544 & -0.113 & 0.000 & -0.038 & 0.058 & 0.005 & 0.360 \\
\hline Married/Civil Partnership & 0.021 & 0.003 & 0.023 & 0.001 & -0.014 & 0.472 & 0.029 & 0.000 \\
\hline Widowed/Divorced/Separated & 0.013 & 0.162 & 0.034 & 0.000 & -0.003 & 0.903 & 0.006 & 0.295 \\
\hline 1 dependent child & 0.010 & 0.220 & 0.025 & 0.001 & 0.019 & 0.318 & 0.000 & 0.927 \\
\hline 2 dependent children & 0.051 & 0.000 & 0.073 & 0.000 & 0.055 & 0.018 & 0.022 & 0.000 \\
\hline $3+$ dependent children & 0.079 & 0.000 & 0.146 & 0.000 & 0.059 & 0.161 & 0.038 & 0.000 \\
\hline Dependent Children N/A & 0.012 & 0.115 & -0.001 & 0.910 & -0.014 & 0.439 & 0.019 & 0.000 \\
\hline Pseudo R-Squared & \multicolumn{2}{|c|}{0.038} & \multicolumn{2}{|c|}{0.107} & \multicolumn{2}{|c|}{0.040} & \multicolumn{2}{|c|}{0.021} \\
\hline Number of Observations & \multicolumn{2}{|c|}{16,240} & \multicolumn{2}{|c|}{17,800} & \multicolumn{2}{|c|}{3,159} & \multicolumn{2}{|c|}{51,077} \\
\hline
\end{tabular}

Notes: Default categories are arrived before 1990, main language is English, aged 16-24, no qualifications, lives in London, single and no dependent children. 
Table 8: Estimates of the Probability of Having Employees by Migrant Category

\begin{tabular}{|c|c|c|c|c|c|c|c|c|}
\hline & \multicolumn{2}{|c|}{ Old-EU } & \multicolumn{2}{|c|}{ New-EU } & \multicolumn{2}{|c|}{ Other Europe } & \multicolumn{2}{|c|}{ Outside Europe } \\
\hline & M.E. & p-value & M.E. & p-value & M.E. & p-value & M.E. & p-value \\
\hline Arrived in 1990s & 0.010 & 0.555 & -0.033 & 0.108 & 0.030 & 0.399 & -0.034 & 0.000 \\
\hline Arrived 2000-3 & -0.017 & 0.517 & -0.077 & 0.000 & -0.012 & 0.800 & -0.039 & 0.001 \\
\hline Arrived 2004-6 & -0.028 & 0.248 & -0.094 & 0.000 & -0.002 & 0.965 & -0.080 & 0.000 \\
\hline Arrived 2007-9 & -0.005 & 0.859 & -0.077 & 0.000 & -0.085 & 0.070 & -0.113 & 0.000 \\
\hline Arrived 2010-11 & -0.066 & 0.015 & -0.085 & 0.000 & 0.017 & 0.816 & -0.080 & 0.000 \\
\hline Speaks English very well & -0.016 & 0.299 & -0.006 & 0.711 & 0.078 & 0.021 & 0.043 & 0.000 \\
\hline Speaks English well & -0.014 & 0.526 & -0.004 & 0.816 & 0.075 & 0.030 & 0.050 & 0.000 \\
\hline Does not speak English well & -0.035 & 0.461 & -0.030 & 0.091 & 0.029 & 0.578 & 0.053 & 0.002 \\
\hline $\begin{array}{l}\text { Does not speak English at all } \\
\text { well }\end{array}$ & 0.268 & 0.162 & -0.006 & 0.867 & 0.018 & 0.921 & 0.122 & 0.057 \\
\hline Aged 25-34 & -0.026 & 0.582 & -0.023 & 0.187 & 0.016 & 0.809 & -0.073 & 0.004 \\
\hline Aged 35-44 & 0.015 & 0.755 & -0.020 & 0.276 & 0.023 & 0.751 & -0.062 & 0.018 \\
\hline Aged 45-54 & 0.025 & 0.626 & -0.017 & 0.418 & 0.041 & 0.586 & -0.075 & 0.004 \\
\hline Aged 55-64 & 0.022 & 0.680 & -0.009 & 0.742 & 0.080 & 0.381 & -0.064 & 0.015 \\
\hline GCSEs or equivalent & -0.053 & 0.020 & -0.001 & 0.951 & -0.033 & 0.415 & -0.003 & 0.784 \\
\hline A Levels/Apprenticeship & -0.024 & 0.324 & -0.021 & 0.260 & -0.054 & 0.248 & -0.029 & 0.046 \\
\hline Degree & 0.016 & 0.503 & -0.028 & 0.059 & -0.092 & 0.015 & 0.015 & 0.195 \\
\hline Other qualification & 0.011 & 0.644 & -0.038 & 0.004 & -0.045 & 0.197 & -0.009 & 0.428 \\
\hline South/East England & -0.017 & 0.240 & -0.018 & 0.123 & -0.029 & 0.325 & -0.012 & 0.165 \\
\hline Midlands & -0.013 & 0.544 & 0.028 & 0.115 & -0.060 & 0.251 & 0.004 & 0.700 \\
\hline North England & -0.006 & 0.748 & 0.010 & 0.570 & 0.002 & 0.958 & 0.008 & 0.411 \\
\hline Wales/South West & -0.008 & 0.690 & 0.009 & 0.656 & -0.036 & 0.365 & -0.019 & 0.169 \\
\hline Married/Civil Partnership & 0.068 & 0.000 & -0.004 & 0.740 & 0.024 & 0.503 & 0.086 & 0.000 \\
\hline Widowed/Divorced/Separated & 0.044 & 0.054 & 0.014 & 0.386 & 0.041 & 0.351 & 0.049 & 0.001 \\
\hline 1 dependent child & 0.039 & 0.054 & 0.026 & 0.059 & 0.026 & 0.490 & 0.023 & 0.028 \\
\hline 2 dependent children & 0.030 & 0.141 & 0.004 & 0.803 & 0.087 & 0.028 & 0.047 & 0.000 \\
\hline $3+$ dependent children & 0.133 & 0.000 & 0.044 & 0.107 & 0.068 & 0.238 & 0.037 & 0.002 \\
\hline Dependent Children N/A & -0.014 & 0.430 & -0.003 & 0.805 & -0.053 & 0.138 & 0.018 & 0.129 \\
\hline Female & -0.068 & 0.000 & -0.016 & 0.173 & -0.117 & 0.000 & -0.057 & 0.000 \\
\hline Part-time & -0.156 & 0.000 & -0.091 & 0.000 & -0.093 & 0.000 & -0.146 & 0.000 \\
\hline Pseudo R-Squared & \multicolumn{2}{|c|}{0.120} & \multicolumn{2}{|c|}{0.053} & \multicolumn{2}{|c|}{0.160} & \multicolumn{2}{|c|}{0.106} \\
\hline Number of Observations & \multicolumn{2}{|c|}{4,962} & \multicolumn{2}{|c|}{7,098} & \multicolumn{2}{|c|}{1,636} & \multicolumn{2}{|c|}{20,528} \\
\hline
\end{tabular}

Notes: Default categories are arrived before 1990, main language is English, aged 16-24, no qualifications, lives in London, single and no dependent children. Controls for industrial sector have also been included. In particular, 15 dummies from the 21 SIC 2007 sections have been included in the probit models for each of the four categories. A smaller number of categories have been included in comparison to Table 5 because of the need to combine the smaller industrial sections for some of the categories. 


\section{Appendix}

\section{Construction of Migrant Groups and Categories}

The following categories can be identified in the SARs in terms of the respondents' countries of birth.

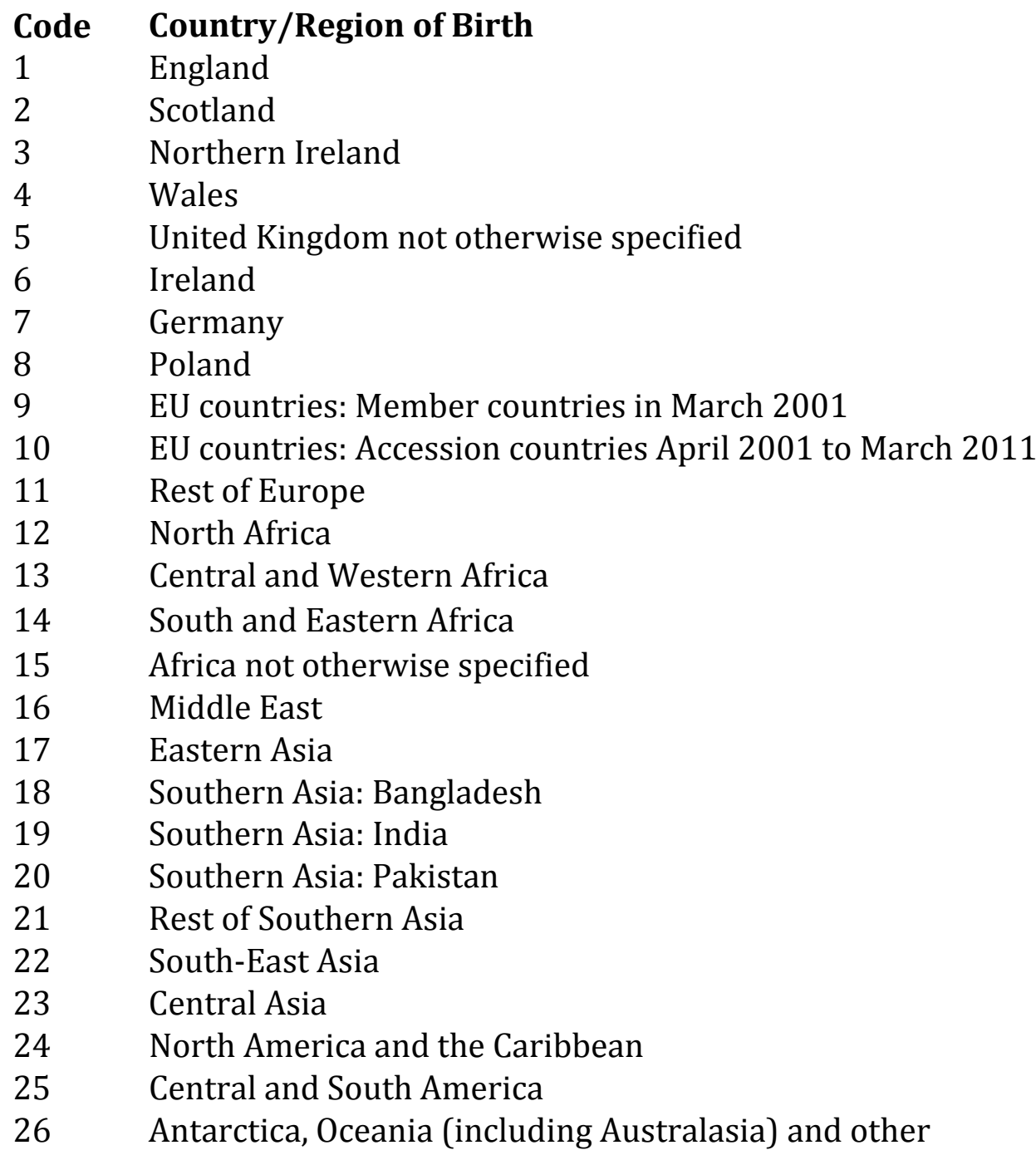

These codes were then used to construct the following groups as a result of sample sizes and geographical considerations.

$\begin{array}{ll}\text { Migrant Group } & \text { SARs Codes } \\ \text { UK } & 1,2,3,4,5 \\ \text { Ireland } & 6 \\ \text { Old-EU } & 7,9 \\ \text { New-EU } & 8,10 \\ \text { Other Europe } & 11 \\ \text { Africa } & 12,13,14,15 \\ \text { India } & 19 \\ \text { Pakistan } & 20\end{array}$


Bangladesh

Other Asia

North America and Caribbean

Central and South America

Oceania

Migrant Category

Old-EU

New-EU

Other Europe

Outside Europe
18

$16,17,21,22,23$

24

25

26

\section{SARs Codes}
$6,7,9$
8,10
11
$12-26$ 
Table A1: Labour Market Statistics by Country/Region of Birth, 2011

\begin{tabular}{|c|c|c|c|c|c|c|c|c|}
\hline & \multicolumn{4}{|c|}{ Males } & \multicolumn{4}{|c|}{ Females } \\
\hline & $\begin{array}{c}\text { Activity } \\
\text { Rate }\end{array}$ & $\begin{array}{l}\text { Emp. } \\
\text { Rate }\end{array}$ & $\begin{array}{c}\text { Emp. Rate } \\
\text { (no students) }\end{array}$ & $\begin{array}{l}\text { Unemp. } \\
\text { Rate }\end{array}$ & $\begin{array}{c}\text { Activity } \\
\text { Rate }\end{array}$ & $\begin{array}{l}\text { Emp. } \\
\text { Rate }\end{array}$ & $\begin{array}{c}\text { Emp. Rate } \\
\text { (no students) }\end{array}$ & $\begin{array}{c}\text { Unemp } \\
\text { Rate }\end{array}$ \\
\hline UK & 82.2 & 76.2 & 80.5 & 8.3 & 73.0 & 69.2 & 72.2 & 6.3 \\
\hline Ireland & 80.0 & 74.8 & 76.9 & 7.0 & 70.8 & 67.9 & 69.9 & 4.5 \\
\hline Old-EU & 80.8 & 76.1 & 85.9 & 7.3 & 72.4 & 68.5 & 76.0 & 6.9 \\
\hline New-EU & 89.5 & 85.9 & 91.0 & 4.9 & 80.1 & 75.7 & 79.1 & 6.3 \\
\hline Other Europe & 76.5 & 71.0 & 79.1 & 8.5 & 55.9 & 50.3 & 55.5 & 12.1 \\
\hline Africa & 81.4 & 73.5 & 78.5 & 12.2 & 68.5 & 61.5 & 64.7 & 13.2 \\
\hline India & 83.6 & 80.1 & 85.5 & 6.7 & 64.1 & 59.0 & 60.6 & 9.5 \\
\hline Pakistan & 78.3 & 72.3 & 77.0 & 10.4 & 29.9 & 24.4 & 23.8 & 20.7 \\
\hline Bangladesh & 81.4 & 73.7 & 75.6 & 11.8 & 32.7 & 26.2 & 25.0 & 23.2 \\
\hline Other Asia & 68.2 & 63.0 & 78.3 & 10.2 & 55.8 & 51.6 & 60.9 & 10.1 \\
\hline North America \& Caribbean & 79.5 & 72.3 & 78.8 & 10.3 & 70.4 & 65.4 & 70.7 & 8.4 \\
\hline Central \& South America & 81.6 & 76.7 & 84.8 & 7.8 & 70.3 & 65.5 & 70.1 & 8.3 \\
\hline Oceania & 90.7 & 87.7 & 91.5 & 3.9 & 83.2 & 80.4 & 83.7 & 3.8 \\
\hline All Countries of Birth & 81.9 & 76.0 & 80.7 & 8.4 & 71.6 & 67.6 & 70.9 & 6.8 \\
\hline
\end{tabular}


Table A2: Estimates of Self-Employment Probabilities from Pooled Models

\begin{tabular}{|c|c|c|c|c|c|c|c|c|c|}
\hline & \multicolumn{3}{|c|}{ Male } & \multicolumn{3}{|c|}{ Female } & \multicolumn{3}{|c|}{ With Employees } \\
\hline & Mean & M.E. & p-value & Mean & M.E. & p-value & Mean & M.E. & p-value \\
\hline Ireland & 0.006 & 0.036 & 0.000 & 0.007 & -0.013 & 0.002 & 0.008 & 0.047 & 0.000 \\
\hline Old-EU & 0.019 & -0.031 & 0.000 & 0.021 & 0.017 & 0.000 & 0.019 & -0.009 & 0.212 \\
\hline New-EU & 0.029 & 0.070 & 0.000 & 0.031 & 0.063 & 0.000 & 0.038 & -0.019 & 0.001 \\
\hline Other Europe & 0.006 & 0.070 & 0.000 & 0.005 & 0.038 & 0.000 & 0.009 & 0.061 & 0.000 \\
\hline Africa & 0.028 & -0.017 & 0.000 & 0.028 & -0.005 & 0.015 & 0.029 & 0.038 & 0.000 \\
\hline India & 0.016 & -0.015 & 0.000 & 0.013 & 0.000 & 0.942 & 0.014 & 0.067 & 0.000 \\
\hline Pakistan & 0.011 & 0.152 & 0.000 & 0.004 & 0.050 & 0.000 & 0.016 & 0.020 & 0.015 \\
\hline Bangladesh & 0.005 & 0.004 & 0.575 & 0.002 & -0.015 & 0.050 & 0.004 & 0.147 & 0.000 \\
\hline Other Asia & 0.023 & 0.010 & 0.003 & 0.022 & 0.022 & 0.000 & 0.027 & 0.094 & 0.000 \\
\hline North America \& Caribbean & 0.009 & -0.029 & 0.000 & 0.011 & 0.003 & 0.327 & 0.010 & -0.016 & 0.089 \\
\hline Central \& South America & 0.003 & -0.028 & 0.000 & 0.004 & 0.022 & 0.000 & 0.004 & -0.036 & 0.017 \\
\hline Oceania & 0.005 & 0.013 & 0.058 & 0.006 & 0.021 & 0.000 & 0.006 & -0.030 & 0.013 \\
\hline Aged 25-34 & 0.236 & 0.091 & 0.000 & 0.233 & 0.042 & 0.000 & 0.174 & -0.002 & 0.714 \\
\hline Aged 35-44 & 0.253 & 0.159 & 0.000 & 0.255 & 0.086 & 0.000 & 0.271 & 0.018 & 0.003 \\
\hline Aged 45-54 & 0.244 & 0.199 & 0.000 & 0.259 & 0.102 & 0.000 & 0.293 & 0.020 & 0.001 \\
\hline Aged 55-64 & 0.164 & 0.257 & 0.000 & 0.148 & 0.142 & 0.000 & 0.219 & 0.008 & 0.215 \\
\hline 0-4 GCSEs or equivalent & 0.143 & -0.024 & 0.000 & 0.148 & -0.006 & 0.000 & 0.139 & -0.002 & 0.594 \\
\hline 5+ GCSEs or equivalent & 0.146 & -0.029 & 0.000 & 0.184 & -0.001 & 0.553 & 0.143 & -0.007 & 0.062 \\
\hline Apprenticeship & 0.059 & 0.020 & 0.000 & 0.010 & 0.136 & 0.000 & 0.061 & -0.020 & 0.000 \\
\hline $2+$ A Levels or equivalent & 0.137 & -0.030 & 0.000 & 0.145 & 0.010 & 0.000 & 0.128 & -0.009 & 0.017 \\
\hline Degree & 0.343 & -0.062 & 0.000 & 0.379 & 0.019 & 0.000 & 0.336 & 0.026 & 0.000 \\
\hline Other qualification & 0.063 & -0.025 & 0.000 & 0.046 & 0.017 & 0.000 & 0.069 & -0.004 & 0.437 \\
\hline North West & 0.120 & 0.035 & 0.000 & 0.123 & 0.013 & 0.000 & 0.106 & -0.018 & 0.002 \\
\hline Yorkshire \& the Humber & 0.092 & 0.035 & 0.000 & 0.091 & 0.015 & 0.000 & 0.081 & -0.020 & 0.000 \\
\hline East Midlands & 0.081 & 0.035 & 0.000 & 0.081 & 0.021 & 0.000 & 0.073 & -0.024 & 0.000 \\
\hline West Midlands & 0.096 & 0.042 & 0.000 & 0.096 & 0.017 & 0.000 & 0.088 & -0.034 & 0.000 \\
\hline East of England & 0.109 & 0.064 & 0.000 & 0.107 & 0.034 & 0.000 & 0.111 & -0.038 & 0.000 \\
\hline Inner London & 0.063 & 0.122 & 0.000 & 0.062 & 0.092 & 0.000 & 0.076 & -0.034 & 0.000 \\
\hline Outer London & 0.090 & 0.113 & 0.000 & 0.089 & 0.049 & 0.000 & 0.108 & -0.041 & 0.000 \\
\hline South East & 0.160 & 0.072 & 0.000 & 0.159 & 0.042 & 0.000 & 0.172 & -0.047 & 0.000 \\
\hline South West & 0.095 & 0.075 & 0.000 & 0.097 & 0.052 & 0.000 & 0.106 & -0.045 & 0.000 \\
\hline Wales & 0.051 & 0.047 & 0.000 & 0.052 & 0.021 & 0.000 & 0.048 & -0.018 & 0.005 \\
\hline Married & 0.505 & -0.002 & 0.154 & 0.489 & 0.020 & 0.000 & 0.577 & 0.077 & 0.000 \\
\hline Civil Partnership & 0.003 & -0.001 & 0.859 & 0.003 & 0.060 & 0.000 & 0.004 & 0.054 & 0.003 \\
\hline Separated & 0.026 & 0.004 & 0.214 & 0.036 & 0.001 & 0.507 & 0.031 & 0.044 & 0.000 \\
\hline Divorced & 0.079 & 0.014 & 0.000 & 0.113 & 0.004 & 0.018 & 0.104 & 0.030 & 0.000 \\
\hline Widowed & 0.006 & -0.005 & 0.434 & 0.016 & 0.001 & 0.828 & 0.011 & 0.088 & 0.000 \\
\hline 1 dependent child & 0.159 & 0.011 & 0.000 & 0.197 & 0.008 & 0.000 & 0.162 & 0.022 & 0.000 \\
\hline 2 dependent children & 0.145 & 0.022 & 0.000 & 0.156 & 0.028 & 0.000 & 0.163 & 0.037 & 0.000 \\
\hline $3+$ dependent children & 0.055 & 0.062 & 0.000 & 0.048 & 0.052 & 0.000 & 0.070 & 0.057 & 0.000 \\
\hline Dependent Children N/A & 0.203 & -0.008 & 0.000 & 0.155 & 0.012 & 0.000 & 0.178 & 0.007 & 0.033 \\
\hline Female & - & - & - & - & - & - & 0.299 & -0.017 & 0.000 \\
\hline
\end{tabular}


Part-time

Mining \& Quarrying

Manufacturing

Electricity, Gas etc

Water Supply; Sewerage etc

Construction

Wholesale and Retail

Transportation and Storage

Accommodation and Food

Information and Comm.

Financial and Insurance

Real Estate

Professional Sci. \& Tech.

Administrative and Support

Public Admin. \& Defence

Education

Health and Social Work

Arts \& Entertainment

Other Service Activities

Households as Employers

Extra-Territorial Orgs

Pseudo R-squared

Number of Observations

\begin{tabular}{|c|c|c|c|c|c|c|c|c|}
\hline - & - & - & - & - & - & 0.284 & -0.144 & 0.000 \\
\hline - & - & - & - & - & - & 0.001 & -0.100 & 0.000 \\
\hline - & - & - & - & - & - & 0.056 & 0.005 & 0.439 \\
\hline - & - & - & - & - & - & 0.002 & -0.086 & 0.000 \\
\hline - & - & - & - & - & - & 0.003 & 0.022 & 0.208 \\
\hline - & - & - & - & - & - & 0.220 & -0.079 & 0.000 \\
\hline - & - & - & - & - & - & 0.118 & 0.071 & 0.000 \\
\hline - & - & - & - & - & - & 0.061 & -0.068 & 0.000 \\
\hline - & - & - & - & - & - & 0.045 & 0.265 & 0.000 \\
\hline - & - & - & - & - & - & 0.047 & -0.088 & 0.000 \\
\hline - & - & - & - & - & - & 0.023 & -0.047 & 0.000 \\
\hline - & - & - & - & - & - & 0.016 & 0.034 & 0.001 \\
\hline - & - & - & - & - & - & 0.101 & 0.001 & 0.862 \\
\hline- & - & - & - & - & - & 0.064 & -0.028 & 0.000 \\
\hline - & - & - & - & - & - & 0.010 & -0.095 & 0.000 \\
\hline - & - & - & - & - & - & 0.051 & -0.087 & 0.000 \\
\hline - & - & - & - & - & - & 0.067 & 0.034 & 0.000 \\
\hline- & - & - & - & - & - & 0.035 & -0.103 & 0.000 \\
\hline - & - & - & - & - & - & 0.052 & 0.013 & 0.089 \\
\hline- & - & - & - & - & - & 0.002 & -0.126 & 0.000 \\
\hline & & _ & _ & _ & _ & 0.000 & -0.071 & 0.102 \\
\hline & 0.034 & & \multicolumn{3}{|c|}{0.034} & \multicolumn{3}{|c|}{0.081} \\
\hline & 56,518 & & \multicolumn{3}{|c|}{579,926} & \multicolumn{3}{|c|}{186,833} \\
\hline
\end{tabular}

Note: Table reports marginal effects (calculated at sample means) and p-values (calculated using robust standard errors). 
Table A3: Means of Explanatory Variables by Migrant Category

\begin{tabular}{|c|c|c|c|c|c|c|c|c|}
\hline & \multicolumn{2}{|c|}{ Old-EU } & \multicolumn{2}{|c|}{ New-EU } & \multicolumn{2}{|c|}{ Other Europe } & \multicolumn{2}{|c|}{ Outside Europe } \\
\hline & Men & Women & Men & Women & Men & Women & Men & Women \\
\hline Arrived before 1990 & 0.099 & 0.116 & 0.012 & 0.015 & 0.095 & 0.088 & 0.221 & 0.247 \\
\hline Arrived in 1990s & 0.213 & 0.248 & 0.032 & 0.046 & 0.400 & 0.330 & 0.236 & 0.210 \\
\hline Arrived 2000-3 & 0.118 & 0.124 & 0.070 & 0.084 & 0.142 & 0.143 & 0.165 & 0.163 \\
\hline Arrived 2004-6 & 0.173 & 0.164 & 0.426 & 0.397 & 0.147 & 0.184 & 0.163 & 0.178 \\
\hline Arrived 2007-9 & 0.228 & 0.198 & 0.320 & 0.341 & 0.152 & 0.172 & 0.151 & 0.145 \\
\hline Arrived 2010-11 & 0.168 & 0.149 & 0.139 & 0.117 & 0.064 & 0.083 & 0.063 & 0.055 \\
\hline English is main language at home & 0.570 & 0.574 & 0.103 & 0.138 & 0.331 & 0.429 & 0.573 & 0.639 \\
\hline Speaks English very well & 0.284 & 0.309 & 0.204 & 0.284 & 0.298 & 0.339 & 0.189 & 0.172 \\
\hline Speaks English well & 0.121 & 0.098 & 0.449 & 0.382 & 0.282 & 0.170 & 0.182 & 0.141 \\
\hline Does not speak English well & 0.023 & 0.017 & 0.223 & 0.178 & 0.083 & 0.056 & 0.053 & 0.043 \\
\hline $\begin{array}{l}\text { Does not speak English at } \\
\text { all well }\end{array}$ & 0.002 & 0.002 & 0.022 & 0.019 & 0.006 & 0.004 & 0.004 & 0.004 \\
\hline Aged 16-24 & 0.068 & 0.099 & 0.120 & 0.149 & 0.058 & 0.064 & 0.045 & 0.047 \\
\hline Aged 25-34 & 0.405 & 0.398 & 0.566 & 0.557 & 0.414 & 0.414 & 0.312 & 0.299 \\
\hline Aged 35-44 & 0.328 & 0.304 & 0.209 & 0.171 & 0.329 & 0.302 & 0.334 & 0.323 \\
\hline Aged 45-54 & 0.138 & 0.137 & 0.079 & 0.091 & 0.158 & 0.168 & 0.207 & 0.228 \\
\hline Aged 55-64 & 0.061 & 0.062 & 0.025 & 0.033 & 0.041 & 0.053 & 0.103 & 0.103 \\
\hline No qualifications & 0.064 & 0.042 & 0.140 & 0.119 & 0.215 & 0.089 & 0.183 & 0.143 \\
\hline GCSEs or equivalent & 0.083 & 0.078 & 0.138 & 0.126 & 0.136 & 0.100 & 0.162 & 0.175 \\
\hline A Levels/Apprenticeship & 0.073 & 0.080 & 0.068 & 0.065 & 0.062 & 0.075 & 0.062 & 0.070 \\
\hline Degree & 0.494 & 0.554 & 0.189 & 0.297 & 0.298 & 0.509 & 0.331 & 0.396 \\
\hline Other qualification & 0.286 & 0.246 & 0.464 & 0.393 & 0.290 & 0.228 & 0.261 & 0.216 \\
\hline London & 0.553 & 0.506 & 0.315 & 0.328 & 0.578 & 0.573 & 0.429 & 0.447 \\
\hline South/East England & 0.224 & 0.267 & 0.242 & 0.262 & 0.198 & 0.206 & 0.184 & 0.209 \\
\hline Midlands & 0.064 & 0.062 & 0.175 & 0.160 & 0.063 & 0.067 & 0.161 & 0.146 \\
\hline North England & 0.090 & 0.091 & 0.169 & 0.153 & 0.100 & 0.088 & 0.177 & 0.137 \\
\hline Wales/South West & 0.069 & 0.074 & 0.098 & 0.098 & 0.060 & 0.066 & 0.049 & 0.061 \\
\hline Single & 0.548 & 0.535 & 0.496 & 0.478 & 0.253 & 0.252 & 0.185 & 0.163 \\
\hline Married/Civil Partnership & 0.381 & 0.367 & 0.422 & 0.377 & 0.623 & 0.580 & 0.757 & 0.695 \\
\hline Widowed/Divorced/Separated & 0.072 & 0.098 & 0.082 & 0.145 & 0.123 & 0.168 & 0.059 & 0.142 \\
\hline No dependent children & 0.290 & 0.326 & 0.300 & 0.367 & 0.244 & 0.355 & 0.247 & 0.345 \\
\hline 1 dependent child & 0.125 & 0.158 & 0.174 & 0.218 & 0.188 & 0.217 & 0.180 & 0.223 \\
\hline 2 dependent children & 0.111 & 0.124 & 0.094 & 0.095 & 0.195 & 0.156 & 0.184 & 0.178 \\
\hline $3+$ dependent children & 0.040 & 0.038 & 0.025 & 0.022 & 0.070 & 0.037 & 0.143 & 0.082 \\
\hline Dependent Children N/A & 0.434 & 0.354 & 0.407 & 0.298 & 0.303 & 0.235 & 0.247 & 0.172 \\
\hline Number of Observations & 16,358 & 16,240 & 19,029 & 17,800 & 4,202 & 3,159 & 63,395 & 51,077 \\
\hline
\end{tabular}

